\title{
Effects of Age, Gender, and Comorbid Diseases on Serum Digoxin Levels During Digoxin Treatment
}

Zeynep ÖZTÜRK', Serap ÇUHADAR²

${ }^{1}$ Department of Clinical Pharmacology and Toxicology, İzmir Atatürk Training and Research Hospital, İzmir, Turkey

${ }^{2}$ Medical Biochemistry Laboratory, İzmir Atatürk Training and Research Hospital, İzmir, Turkey

\section{ABSTRACT}

Objective: Digoxin is widely used in controlling ventricular rhythm in atrial fibrillation and heart failure. Therapeutic serum levels of digoxin are $0.5-2 \mathrm{ng} / \mathrm{mL}$. Toxicity may occur after acute accidental or suicidal ingestion or with chronic therapy. In this study, we aimed to determine the frequency of high serum digoxin levels and its association with factors, such as age, gender, and comorbidities.

Methods: A 3-year (January 2009-December 2011) cross-sectional study was performed, and a total of 2480 patients who were hospitalized or visited the outpatient clinics were included in this study. Details of serum digoxin levels, age, gender, and comorbidities were retrospectively retrieved from the laboratory data system.

Results: The mean (range) age was $71.33 \pm 12.24$ (min. 18, max. 97) years and $74.1 \%$ of the patients were elderly (age $\geq 65$ ). The rate of high serum digoxin levels was found to be $17.8 \%$ in our study population $(n=439)$. A total of $87.9 \%$ of the patients with high serum digoxin levels were elderly and $71 \%$ of them were females. The most common symptoms and comorbidities in patients who had serum digoxin levels $>2 \mathrm{ng} / \mathrm{mL}$ were dyspnea and vomiting in females, heart failure and chest pain in males.

Conclusion: This study shows that higher serum digoxin levels are associated with older age and female gender. Increased awareness of medication safety in geriatric population is important. Because of altered pharmacokinetics of digoxin with age, therapeutic monitoring is needed.

Keywords: Digoxin, toxicity, gender, age

\section{Introduction}

Digoxin is a drug that has been used in cardiovascular treatment for many years. It is known to be particularly effective in heart failure and atrial fibrillation (1). In recent years, the clinical use of alternative drugs (such as beta blockers, angiotensin receptor blockers, and angiotensin converting enzyme inhibitors) and the effectiveness of digoxin as the first choice have been controversial (2-4). Furthermore, in some observational studies, it has been suggested that digoxin can increase mortality in patients $(5,6)$. It is known that digoxin is a drug with a narrow therapeutic range, and therefore, it can lead to mortality and hospitalization in patients, in association with the factors that will affect the metabolism of this drug (7). For this reason, serum digoxin levels are measured in order to detect or prevent possible digoxin intoxication.

Digoxin intoxication seems to be one of the main reasons for the restriction of digoxin usage in treatment; moreover, this intoxication can be life-threatening. Digoxin intoxication is one of the most common causes of admission to the emergency unit (7). Therefore, it is important to approach and evaluate the clinical picture accurately. In addition to the measurement of serum digoxin levels, various factors that can cause digoxin intoxication or increased serum levels of the drug should be investigated. The results of epidemiological studies on digoxin toxicity and mortality and morbidity of diseases that are treated with digoxin are different $(5,8,9)$. In this study, we aimed to investigate the relationship of serum digoxin levels, which were measured in the biochemistry laboratory of our hospital, with age, gender, and findings and diagnoses at admission.

Cite this article as: Öztürk Z, Çuhadar S. Effects of Age, Gender, and Comorbid Diseases on Serum Digoxin Levels During Digoxin Treatment. Bezmialem Science 2018; 6: 31-6. 


\section{Methods}

This study was a descriptive and retrospective study. The files of patients whose serum digoxin levels were measured in the Biochemistry Laboratory in İzmir Atatürk Education and Research Hospital between January 2009 and December 2011 were evaluated retrospectively. Serum digoxin levels $>2 \mathrm{ng} /$ $\mathrm{mL}$ were evaluated to be "high." The measured values were compared with age, gender, and diagnoses. Moreover, the distribution of comorbid diseases in patients with high serum digoxin levels was examined according to age and gender.

The diagnoses of diseases were coded in accordance with the International Classification of Diseases-10 at the time of measurement. All patients in the study were $\geq 18$ years of age, and all patients whose serum digoxin levels were measured within the above mentioned dates were included in the study regardless of gender because of the sectional characteristic of the study. The results of the samples re-requested from the same patient were not evaluated. Serum digoxin levels were measured using the immunoturbidimetric method (Architect c16000; Abbott, Wiesbaden, Germany). The ethical approval for the study was received from İzmir Katip Çelebi University, Ethics Committee for Non-Invasive Clinical Research (date, 02.06.2016; decision number, 150).

\section{Statistical analysis}

For statistical analysis, Statistical Package for the Social Sciences 18.0 version (SPSS, Chicago, IL, USA) software was used. The obtained data were presented as numbers, percentages, and means \pm standard deviations. For categorical vari-

\section{Table 1. Serum digoxin levels (ng/mL)}

Serum digoxin levels $(\mathrm{ng} / \mathrm{mL})$

$<0.19$

$0.20-0.80$

$0.81-2.00$

$2.01-5.00$

$>5.00$ n (\%)

$372(15)$

$644(25.9)$

$1025(41.3)$

415 (16.8)

$24(1)$ ables, the differences between the groups were evaluated with the Chi-square and Fisher's Chi-square tests and a value of $\mathrm{p}<0.05$ was accepted to be significant.

\section{Results}

The results of 2,480 patients between January 2009 and December 2011 were found and examined. Of them, 1,550 were female and 930 were male. In the evaluation of the age groups of patients whose serum digoxin levels were requested, patients $\geq 65$ years of age $(n=1,839,74.1 \%)$ were found to be more common. The mean age was recorded as $71.33 \pm 12.24$ (minimum, 18; maximum, 97) years. The distribution of the results of the patients is given in Figure 1 in detail.

Serum digoxin levels of 2,480 patients were examined and were found to be in the therapeutic range to a large extent (41.23\%). Serum digoxin levels of $372(15 \%)$ patients were very low $(<0.19 \mathrm{ng} / \mathrm{mL})$ and those of $24(1 \%)$ patients were $>5 \mathrm{ng} / \mathrm{mL}$. The number of patients with high serum digoxin level was 439 (17.8\%) (Table 1).

In the measurement analysis according to years, 740 of samples belonging to a total of 2,480 patients were found to be evaluated in 2009, 1,024 in 2010, and 716 in 2011. High serum digoxin levels were observed in $14.3 \%$ of the measurements in 2009 , in $18.5 \%$ in 2010 , and in $1.9 \%$ in 2011.

Further, $87.9 \%$ of patients with high serum digoxin levels were $\geq 65$ years. Moreover, $312(71 \%)$ of 439 patients were female, and 127 (29\%) were male. In the evaluation of serum digoxin levels, shown in Table 2 , in female and male patients and in patients $\geq$ or $<65$ years of age, the values did not display a significant distribution in any range. Besides that, a statistical significance was detected in the distribution of patients according to gender (female or not) and age groups ( $\geq 65$ years of age or not) $(\mathrm{p}<0.01$ for both parameters).

The referrals to our biochemistry laboratory for the measurement of serum digoxin levels were mostly from the emergency unit $(1,407$ patients, $56.7 \%)$, followed by the cardiology clinic (250 patients, 10\%), cardiology outpatient clinic (173

Table 2. Distribution of high serum digoxin levels according to age and gender

\begin{tabular}{|c|c|c|c|c|c|}
\hline $\begin{array}{l}\text { Serum digoxin } \\
\text { level (ng/mL) }\end{array}$ & $\begin{array}{c}\text { Total patients, } \\
\mathbf{n}\end{array}$ & $\begin{array}{c}\text { Female patients, } \\
\text { n (\%) }\end{array}$ & $\begin{array}{c}\text { Male patients, } \\
\text { n (\%) }\end{array}$ & $\begin{array}{c}\text { Patients } \geq 65 \\
\text { years of age, } n(\%)\end{array}$ & $\begin{array}{c}\text { Patients }<65 \\
\text { years of age, } n(\%)\end{array}$ \\
\hline $2.01-2.50$ & 161 & $110(68.3)$ & $51(31.7)$ & $138(85.7)$ & $23(14.3)$ \\
\hline $2.51-3.00$ & 119 & $80(67.2)$ & 39 (32.8) & $106(89.1)$ & 13 (10.9) \\
\hline $3.01-3.50$ & 62 & $49(79.1)$ & $13(20.9)$ & $53(85.5)$ & $9(14.5)$ \\
\hline $3.51-4.00$ & 39 & $31(79.5)$ & $8(20.5)$ & 38 (97.5) & $1(2.5)$ \\
\hline $4.01-4.50$ & 19 & $15(79.0)$ & $4(21.0)$ & $18(94.7)$ & $1(5.3)$ \\
\hline $4.51-5.00$ & 15 & $9(60.0)$ & $6(40.0)$ & $12(80.0)$ & $3(20.0)$ \\
\hline$>5.00$ & 24 & $18(75)$ & $6(25)$ & $21(87.5)$ & $3(12.5)$ \\
\hline$>2.00$ & 439 & $312(71.0)$ & $127(29.0)$ & $386(87.9)$ & $53(12.1)$ \\
\hline
\end{tabular}




\begin{tabular}{|c|c|c|c|c|c|}
\hline Comorbid diagnoses & $\begin{array}{c}\text { Total } \\
\text { patients, n }\end{array}$ & $\begin{array}{c}\text { Female } \\
\text { patients, n }\end{array}$ & $\begin{array}{c}\text { Male } \\
\text { patients, n }\end{array}$ & $\begin{array}{c}\text { Patients } \geq 65 \\
\text { years of age, n }\end{array}$ & $\begin{array}{c}\text { Patients }<65 \\
\text { years of age, } n\end{array}$ \\
\hline Dyspnea & 48 & 38 & 10 & 43 & 5 \\
\hline Heart failure & 46 & 28 & 18 & 37 & 9 \\
\hline Chest pain & 43 & 28 & 15 & 41 & 2 \\
\hline Nausea/vomiting & 39 & 33 & 6 & 35 & 4 \\
\hline Atrial fibrillation & 30 & 23 & 7 & 29 & 1 \\
\hline Bradycardia & 20 & 18 & 2 & 20 & 0 \\
\hline Palpitation & 18 & 14 & 4 & 19 & 1 \\
\hline Malaise and fatigue & 16 & 14 & 2 & 16 & 0 \\
\hline Abdominal pain & 14 & 13 & 1 & 13 & 1 \\
\hline Cerebrovascular disorder & 14 & 13 & 1 & 13 & 1 \\
\hline Essential hypertension & 10 & 7 & 3 & 9 & 1 \\
\hline Congestive heart failure & 8 & 4 & 4 & 6 & 2 \\
\hline Pneumonia & 6 & 3 & 3 & 5 & 1 \\
\hline Atherosclerotic heart disease & 6 & 3 & 3 & 6 & 0 \\
\hline Dizziness & 6 & 4 & 2 & 3 & 3 \\
\hline Left ventricular failure & 5 & 3 & 2 & 4 & 1 \\
\hline
\end{tabular}

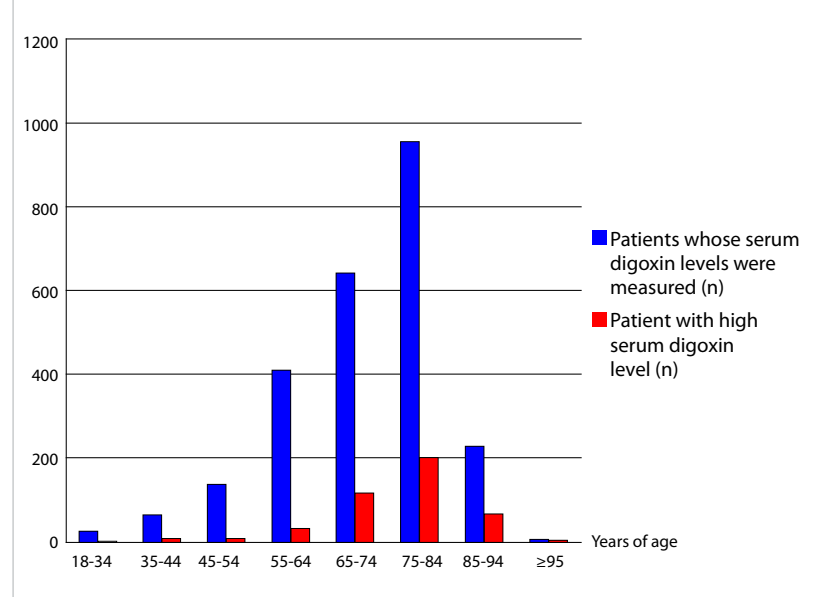

Figure 1. Distribution of serum digoxin levels in the age groups

patients, 6.9\%), internal diseases clinic (163 patients, 6.5\%), and coronary intensive care unit (106 patients, 4.2\%). High digoxin levels (439 patients) were found in patients mostly from the emergency unit (256 patients), cardiology clinic (54 patients), coronary intensive care unit (33 patients), internal diseases clinic (29 patients), and cardiology outpatient clinic (23 patients).

The most common diagnoses accompanying high serum digoxin levels in the patients were dyspnea, heart failure, chest pain, nausea/vomiting, atrial fibrillation, bradycardia, palpitation, malaise and fatigue, abdominal pain, cerebrovascular disorder, and essential hypertension (Table 3). The most common diagnosis was dyspnea in female patients and in patients $\geq 65$ years of age, and the most common diagnosis was heart failure in male patients and in patients $<65$ years of age. Bradycardia, malaise and fatigue, and atherosclerotic heart disease were not observed in patients $<65$ years of age. Conversely, abdominal pain, cerebrovascular disorder, and bradycardia were mostly observed in female patients.

The detailed distribution of the diagnoses accompanying high serum digoxin levels in patients $\geq 65$ years of age is given in Table 4 according to age groups. Nausea/vomiting, cerebrovascular disorder, congestive heart failure, pneumonia, atherosclerotic heart disease, dizziness, and left ventricular failure were not included among the diagnoses of patients in the age range of 65-69 years. Conversely, cerebrovascular disorder, congestive heart failure, and atherosclerotic heart disease were observed to become more common for patients in the age range of 80-89 years.

\section{Discussion}

Digoxin is one of the oldest drugs used in the clinical treatment of heart diseases (9). It is primarily used for controlling heart rate in the treatment of atrial fibrillation and congestive heart failure. The measurement of the serum levels of this drug, which has a narrow therapeutic range and can require long-term usage, for control or in cases of suspicion of intoxication can guide doctors, particularly, in patients with clinical findings. Only high serum digoxin level is not enough to establish the diagnosis of digoxin intoxication because distri- 
Table 4. Distribution of diagnoses accompanying high serum digoxin levels in patients $\geq 65$ years of age

\begin{tabular}{|c|c|c|c|c|c|}
\hline Comorbid diagnosis & $\begin{array}{c}\text { Age of } \geq 65 \\
\text { years, } n\end{array}$ & $\begin{array}{c}\text { Age of 65-69 } \\
\text { years, } n\end{array}$ & $\begin{array}{c}\text { Age of } 70-79 \\
\text { years, } n\end{array}$ & $\begin{array}{c}\text { Age of 80-89 } \\
\text { years, } n\end{array}$ & $\begin{array}{c}\text { Age of } \geq 90 \\
\text { years, } n\end{array}$ \\
\hline Dyspnea & 43 & 5 & 16 & 20 & 2 \\
\hline Heart failure & 37 & 5 & 18 & 14 & 0 \\
\hline Chest pain & 41 & 8 & 14 & 18 & 1 \\
\hline Nausea/vomiting & 35 & 0 & 16 & 19 & 0 \\
\hline Atrial fibrillation & 29 & 1 & 8 & 19 & 1 \\
\hline Bradycardia & 20 & 4 & 5 & 10 & 1 \\
\hline Palpitation & 19 & 2 & 10 & 4 & 1 \\
\hline Malaise and fatigue & 16 & 4 & 3 & 8 & 1 \\
\hline Abdominal pain & 13 & 1 & 7 & 5 & 0 \\
\hline Cerebrovascular disorder & 13 & 0 & 3 & 8 & 2 \\
\hline Essential hypertension & 9 & 1 & 4 & 3 & 1 \\
\hline Congestive heart failure & 6 & 0 & 1 & 5 & 0 \\
\hline Pneumonia & 5 & 0 & 4 & 1 & 0 \\
\hline Atherosclerotic heart disease & 6 & 0 & 1 & 5 & 0 \\
\hline Dizziness & 3 & 0 & 1 & 1 & 1 \\
\hline Left ventricular failure & 4 & 0 & 2 & 2 & 0 \\
\hline
\end{tabular}

bution volume of digoxin is quite wide, and serum levels do not give information about the distribution of digoxin in the tissues (10).

Epidemiological studies on atrial fibrillation and congestive heart failure demonstrate that being male and of advanced age are risk factors $(11,12)$. In addition, the risk of stroke and mortality in atrial fibrillation is higher in female patients than in male patients, and high blood pressure and heart failure with preserved ejection fraction are more common, particularly in older female patients than in male patients $(13,14)$. According to the results of our study, the majority of patients whose serum digoxin measurements were requested were female, and the number of female patients was 1.66 times higher than that of male patients. Approximately 3 of 4 patients were $\geq 65$ years of age. In conclusion, most of the patients whose samples were evaluated were elderly and female. This supports the hypothesis that heart diseases requiring the use of digoxin become complicated in elderly female patients more frequently. As shown in Figure 1, the measurement of serum digoxin levels was performed mostly for patients in the age group of 75-84 years, and high levels were found in patients in this age group at a rate higher than that in other groups.

Serum digoxin levels were $>2 \mathrm{ng} / \mathrm{mL}$ in 439 (17.8\%) of 2,480 patients whose levels were measured. Further, $41.3 \%$ of the measurements were recorded to be in the therapeutic range of 0.8-2 ng/mL. In our study, the presence of a significant relationship between high serum digoxin levels and female gender and advanced age can be attributed to the fact that most advanced age. It was reported in previous studies that the rate of hospitalization was higher in elderly female patients receiving digoxin therapy compared to that in other patients (15).

In the comparison of time intervals in which serum digoxin levels were measured (2009-2011), an increase was detected in 2010 compared to that in the other years. The detection rates of high serum digoxin levels have increased slightly over the years. Although some studies on this subject have suggested a decrease in digoxin toxicity cases in the 2000s (16, 17), recent studies have revealed an increase in digoxin toxicity cases with high serum digoxin levels, which is similar to the results of our study (18).

Most of the admissions and high measurement values were of patients visiting the emergency unit. A significant proportion of them were from the cardiology clinic, outpatient clinic, and coronary intensive care unit. In parallel to these results, the accompanying diagnoses were observed to be mostly poisoning findings (dyspnea, chest pain, nausea/vomiting, bradycardia, palpitation, fatigue, and abdominal pain), heart failure, and atrial fibrillation. Vomiting, abdominal pain, chest pain, dyspnea, and sinus bradycardia were observed frequently in acute intoxication by digoxin. In addition, ventricular tachycardia or fibrillation can develop. In chronic intoxication cases, visual impairments, fatigue, sinus bradycardia, atrial fibrillation with retarded ventricular response, or ventricular arrhythmia (ventricular tachycardia and ventricular fibrillation) can occur (19). Dyspnea and heart failure are the most frequently reported diagnoses in female and male patients, respectively. This suggests that digoxin toxicity is more symptomatic in 
female patients, and the known diagnosis of heart failure in male patients has existed previously.

The most important limitation of our study is that other parameters, particularly serum creatinine, which could affect the pharmacokinetics of digoxin, were not included in the measurement analysis because they could cause remarkable changes in the sampling size. Conversely, the evaluation of results obtained from retrospectively reliable measurements in a large sample is valuable for revealing statistical significance.

\section{Conclusion}

In this study, serum digoxin levels analyzed in our laboratory between 2009 and 2011 were evaluated based on the value of $2 \mathrm{ng} / \mathrm{mL}$, which is the upper limit of the known therapeutic concentration range. The commonly used range for the measurement of serum digoxin levels is $0.8-2.0 \mathrm{ng} / \mathrm{mL}$. This concentration range can be used for evaluating digoxin toxicity with clinical findings, rather than the drug effectiveness $(2,20)$. Retrospective analyses performed in the 2000 s have revealed that mortality increases in patients with serum digoxin levels $>1 \mathrm{ng} / \mathrm{mL}$ and decreases in patients with levels $<0.8 \mathrm{ng} / \mathrm{mL}(21,22)$. In some clinical guidelines that have recently been published in Europe and America, there are some views about changing the therapeutic serum digoxin levels to $0.5-1.0 \mathrm{ng} / \mathrm{mL}(23,24)$, which supports the results of the above mentioned studies. Despite agreement on this point, the value of $2.0 \mathrm{ng} / \mathrm{mL}$ is still used as the upper limit for the measurement of digoxin in many laboratories (25). To target low drug concentrations can have negative outcomes, such as subtherapeutic drug concentrations. However, serum digoxin levels can provide information only in the evaluation of toxicity with clinical findings. Therefore, evaluation of the clinical picture together with other factors such as gender, age, and accompanying findings and diseases will be the most effective.

Ethics Committee Approval: Ethics committee approval was received for this study from the Non-Interventional Clinical Studies Ethics Committee of Izmir Katip Celebi University (Date: 02.06.2016, Decision No: 150).

Informed Consent: Written informed consent was not obtained from patients due to the retrospective design of study.

Peer-review: Externally peer-reviewed.

Author Contributions: Concept - Z.Ö., S.Ç.; Design - Z.Ö., S.Ç.; Supervision - Z.Ö., S.Ç.; Resource - Z.Ö., S.Ç.; Materials - Z.Ö., S.Ç.; Data Collection and/or Processing - Z.Ö.; Analysis and/or Interpretation - Z.Ö.; Literature Search - Z.Ö., S.Ç.; Writing - Z.Ö.; Critical Reviews - Z.Ö., S.Ç.

Conflict of Interest: No conflict of interest was declared by the authors.

Financial Disclosure: The authors declared that this study has received no financial support.

\section{References}

1. Eichhorn EJ, Gheorghiade M. Digoxin. Prog Cardiovasc Dis 2002; 44: 251-66. [CrossRef]

2. Friberg L, Hammar N, Rosenqvist M. Digoxin in atrial fibrillation: report from the Stockholm Cohort study of Atrial Fibrillation (SCAF). Heart 2010; 96: 275-80. [CrossRef]

3. Fauchier L, Grimard C, Pierre B, Nonin E, Gorin L, Rauzy $\mathrm{B}$, et al. Comparison of beta blocker and digoxin alone and in combination for management of patients with atrial fibrillation and heart failure.Am J Cardiol 2009; 103: 248-54. [CrossRef]

4. Dhaliwal AS, Bredikis A, Habib G, Carabello BA, Ramasubbu K, Bozkurt B. Digoxin and clinical outcomes in systolic heart failure patients on contemporary background heart failure therapy. Am J Cardiol 2008; 102: 1356-60. [CrossRef]

5. Turakhia MP, Santangeli P, Winkelmayer WC, Xu X, Ullal AJ, Than CT, et al. Increased mortality associated with digoxin in contemporary patients with atrial fibrillation: findings from the TREAT-AF study. J Am Coll Cardiol 2014; 64: 660-8. [CrossRef]

6. Shah M, Avgil Tsadok M, Jackevicius CA, Essebag V, Behlouli $\mathrm{H}$, Pilote L. Relation of digoxin use in atrial fibrillation and the risk of all-cause mortality in patients $\geq 65$ years of age with versus without heart failure. Am J Cardiol 2014; 114: 401-6. [CrossRef]

7. Hafner JW, Belknap SM, Squillante MD, Bucheit KA. Adverse drug events in emergency department patients.Ann Emerg Med 2002; 39: 258-67. [CrossRef]

8. Gheorghiade M, Harinstein ME, Filippatos GS. Digoxin for the treatment of chronic and acute heart failure syndromes. Acute Card Care 2009; 11: 3-7. [CrossRef]

9. Vivo RP, Krim SR, Perez J, Inklab M, Tenner T Jr, Hodgson J. Digoxin: current use and approach to toxicity. Am J Med Sci 2008; 336: 423-8. [CrossRef]

10. Beller GA, Smith TW, Abelmann WH, Haber E, Hood WB Jr. Digitalis intoxication. A prospective clinical study with serum level correlations. N Engl J Med 1971; 284: 989-97. [CrossRef]

11. He J, Ogden LG, Bazzano LA, Vupputuri S, Loria C, Whelton PK. Risk factors for congestive heart failure in US men and women: NHANES I epidemiologic follow-up study. Arch Intern Med. 2001; 161: 996-1002. [CrossRef]

12. Rathore SS, Wang Y, Krumholz HM. Sex-based differences in the effect of digoxin for the treatment of heart failure. N Engl J Med 2002; 347: 1403-11. [CrossRef]

13. Poli D, Antonucci E. Epidemiology, diagnosis, and management of atrial fibrillation in women. Int J Womens Health 2015; 7: 605-14. [CrossRef]

14. Ko D, Rahman F, Schnabel RB, Yin X, Benjamin EJ, Christophersen IE. Atrial fibrillation in women: epidemiology, pathophysiology, presentation, and prognosis. Nat Rev Cardiol 2016; 13: 321-32. [CrossRef]

15. Dagres N, Nieuwlaat R, Vardas PE, Andresen D, Lévy S, Cobbe $S$, et al. Gender-related differences in presentation, treatment, and outcome of patients with atrial fibrillation in Europe: a report from the Euro Heart Survey on Atrial Fibrillation. J Am Coll Cardiol 2007; 49: 572-7. [CrossRef]

16. Haynes K, Heitjan D, Kanetsky P, Hennessy S. Declining public health burden of digoxin toxicity from 1991 to 2004. Clin Pharmacol Ther 2008; 84: 90-4. [CrossRef]

17. Hussain Z, Swindle J, Hauptman PJ. Digoxin use and digoxin toxicity in the post-DIG trial era. J Card Fail 2006; 12: 343-6. [CrossRef] 
18. See I, Shehab N, Kegler SR, Laskar SR, Budnitz DS. Emergency department visits and hospitalizations for digoxin toxicity: United States, 2005 to 2010. Circ Heart Fail 2014; 7: 28-34. [CrossRef]

19. Olson K. Poisoning And Drug Overdose 5th ed. New York: McGraw-Hill, 2006. p. 128.

20. Terra SG, Washam JB, Dunham GD, Gattis WA. Therapeutic range of digoxin's efficacy in heart failure: what is the evidence? Pharmacotherapy 1999; 19: 1123-6.

21. Rathore SS, Curtis JP, Wang Y, Bristow MR, Krumholz HM. Association of serum digoxin concentration and outcomes in patients with heart failure. JAMA 2003; 289: 871-8. [CrossRef]

22. Adams KF Jr, Gheorghiade M, Uretsky BF, Patterson JH, Schwartz TA, Young JB. Clinical benefits of low serum digoxin concentrations in heart failure. J Am Coll Cardiol 2002; 39: 946-53. [CrossRef]
23. Lindenfeld J, Albert NM, Boehmer JP, Collins SP, Ezekowitz JA, Givertz MM, et al. HFSA 2010 comprehensive heart failure practice guideline. J Card Fail 2010; 16: e1-194.

24. McMurray JJ, Adamopoulos S, Anker SD, Auricchio A, Böhm $\mathrm{M}$, Dickstein $\mathrm{K}$, et al. ESC guidelines for the diagnosis and treatment of acute and chronic heart failure 2012: the Task Force for the Diagnosis and Treatment of Acute and Chronic Heart Failure 2012 of the European Society of Cardiology. Developed in collaboration with the Heart Failure Association (HFA) of the ESC. Eur Heart J 2012; 33: 1787-847.

25. Hauptman PJ, McCann P, Romero JM, Mayo M. Reference laboratory values for digoxin following publication of Digitalis Investigation Group (DIG) trial data. JAMA Int Med 2013; 173: 1552-4. [CrossRef] 